\title{
Towards Assessing the Vernacular in the Arabic Language: A Descriptive Analytical Study
}

\author{
Khader T. Khader ${ }^{1}$ \& Usama Hammad ${ }^{2}$ \\ ${ }^{1}$ Department of English, Islamic University of Gaza, Palestine \\ ${ }^{2}$ Department of Arabic, Islamic University of Gaza, Palestine \\ Correspondence: Khader T. Khader, English Department, Islamic University of Gaza, Gaza, Palestine. Tel: \\ 970-8-264-4400. E-mail: KKhader@iugaza.edu.ps
}

\author{
Received: April 24, 2017 Accepted: May 18, 2017 Online Published: July 26, 2017 \\ doi:10.5539/ijel.v7n5p164 URL: http://doi.org/10.5539/ijel.v7n5p164
}

\begin{abstract}
This research aims to highlight the nature of vernacular in the Arabic language, reasons for their emergence, their importance and natural role. It seeks to achieve a balanced relationship between vernacular and the standard language in a scholarly and objective manner. Vernacular is not an undesirable phenomenon people should seek to treat. It is rather a practice Allah prescribed to humankind, a natural human phenomenon that cannot be eradicated. We shall keep pace and coexist with it. Vernaculars play an obvious humanitarian role; they perform social mission in their own environments. A standard language cannot supersede the vernacular. This is conditioned on that vernaculars should play their role in their own fields. A standard language enjoys a status, role and platforms, which cannot be shared with vernacular. Their relation remains complementary.
\end{abstract}

Keywords: language, standard, dialect, vernacular, relationship and status

\section{Introduction}

Vernacular is a deeply rooted humanitarian phenomenon. It cannot be excluded from the human reality. There is a need to accept and coexist with vernacular. In addition, vernacular could be rationalized to achieve a strong relationship with the standard language from which vernacular originated. Each variety has its own fields.

Spoken by over 200 million people across Middle East and North Africa, the Arabic language has a variety of dialects. It is the official language of most of the Arab countries; Saudi Arabia, Libya, Morocco, Syria, Tunisia etc. It belongs to the Semitic subfamily of the Afro-Asiatic family of languages and it has 28 alphabet that has been borrowed by some other languages like Urdu (Note 1).

Ibn Jinni defines language as, "Voices each nation uses to express their purposes." (Note 2) Contemporary scholars' definitions are consistent with this precise definition. The elements of language definition by the contemporary researchers are consistent with Ibn Jinni definition in essence after being praised by the ancient researchers. Scholars define dialect in the contemporary scholarly terminology as: It is a set of linguistic characteristics of a certain environment that all members of this environment share. This indicates a complementary relationship between standard Arabic and Arabic dialects.

The importance of language mission is similar in all languages. The difference between the standard language and the vernacular lies in the field of usage, types of objectives to be achieved and users. It is worth mentioning here that there is a need to have a balanced view on the matter without excess. It is fair to assume a middle stand in this context.

The significance of this research lies in the vast discrepancy between vernaculars, their nature and mission, the arguments of those who oppose them and those who argue for them, giving preference to them as compared to the standard language. Some argue that the Standard Arabic language is poor and unable to keep pace with the scientific development. There are abundant studies on different aspects of vernacular including vocabulary, phrases, structures, styles in all languages but Arabic. This research focuses on the balanced linguistic usage. It warns against those who criticize people for not using the standard language in public life and those who argue that the standard language is poor and is the cause for the misfortunes and catastrophes of the Arabs.

The research also emphasizes the complementary nature between the standard language and the vernacular. We 
shall see that there is a need for the joint existence of the vernacular and the standard language, each with indispensable mission.

\section{Vernacular Reality}

Vernacular is a human phenomenon, which cannot disappear. This is evidenced in Quran, 49:13 "O mankind! We have created you from a male and a female, and made you into nations and tribes, that you may know each other." People cannot survive using one language. The difference in the nature of human beings and their circumstances including languages is a divinely prescribed reality. This understanding indicates that denying vernacular means denying a divinely prescribed practice.

It is important to keep in mind that vernaculars, language variation and language change are three separate processes, though they are not completely unrelated to each other. In order for a linguistic feature to change across an entire dialect, there must always have been a period during, which that feature was unstable and in variation (Labov, 1972).

The Arabic language is a loose term that refers to the many existing varieties of Arabic. Those varieties include one "written" form, Modern Standard Arabic (MSA), and many "spoken" forms, each of which is a regional dialect. MSA is the only variety that is standardized, regulated, and taught in schools, necessitated by its use in written communication and formal venues. The regional dialects, used primarily for day-to-day dealings and spoken communication, remain somewhat absent from written communication compared to MSA. That said, it is certainly possible to produce dialectal Arabic text, by using the same letters used in MSA and the same (mostly phonetic) spelling rules of MSA (Zaidan \& Callison-Burch, 2014).

\section{Section One: how vernacular emerged}

It is narrated that Isma'il was the first to speak Arabic. However, the Arabic language meant in this context is the language in which the Holy Quran was revealed and the language which people spoke during the era of the Prophet. But the Arabic which Isma'il spoke was different. Language or dialect is evolving and living. All human languages are subject to change. Some languages may disappear while others may change. It is natural that dialects differ in human society. Lughah "لغ" (lit. language) denotes deviation. Lagha "غلغة" means that someone is not following the right track. This is because some spoke in a manner which deviates from the manner in which others spoke. Therefore, it was narrated that Isma'il was the first to speak Arabic and forgot the language of his father.

The Holy Quran highlighted this difference in chapter 30, verse 22 "And among His Signs is the creation of the heavens and the earth, and the variations in your languages." It also stressed the difference among humans on every level by Saying "and if your Lord had willed, He could have made mankind one community; but they will not cease to differ," Quran, 11:118. It is enough to mention that the Quran itself indicated that it was revealed in seven dialects. Muhammad, Peace be Upon Him said, "the Holy Quran has revealed in seven dialects, each is sufficient." The most favorable views on the dialects show that they refer to the Arabic dialects. This indicates that Quran itself took into account the difference in dialects among humans because it is a divinely prescribed will that cannot be ignored. Some scholars argue that the Holy Quran readings offer the most comprehensive sources for the study of ancient Arabic dialects. Some scholars stated that Quran contains forty dialect. Some scholars authored books on the dialects of the Holy Quran such as: The Languages of Quran by Hisham al-Kalbi, The Languages of Quran by al-Farra and The Languages in Quran by al-Asma'e, and others books.

Ulman believes that language is in constant change in its sounds, structures, grammatical elements, formulas and meanings regardless of the speed of this change. This change takes place due to the norms and regulations. It is possible that such change was initiated through a renewal by a person or persons. If the change was accepted in a language community, it would move to another phase, called the spreading phase. Thus, this change becomes integral to the language promoted by its use. Languages have their own dialects. In addition, people differ in one village in their use of language. Their speech is controlled by age, social status, interests and other reasons. It is sometimes difficult to determine such precise discrepancies among the members of one village.

The call of some researchers to use the standard language in communication and to eradicate vernacular cannot be reasonably justified. A scholar says "It is sufficient for me to mention here the fair decision made by the orientalists at their conference in Greece. They said that Standard Arabic is the language that is suitable for the Islamic and Arab countries in terms of communicating, writing and authoring. It is the duty of the Arab governments in such countries to spread the use of Standard Arabic among the social classes to eradicate vernacular which are not suitable for the nations united by religion, customs and traditions."

Is there call, which is stranger than this call? How can this researcher think about eradicating a deeply-rooted 
phenomenon in the human sense and human system? Perhaps it is necessary here to indicate that despite the considerable efforts made to serve the standard language during over hundreds of years, such efforts did not prevent the emergence of variation in language and the birth of new dialects. The aforementioned efforts were supported by the whole society including rulers, elite intellectual and religious figures because. The efforts were religious in nature because the standard language is the language of Holy Quran. Despite that, and the risks and importance associated thereto, it was not possible to prevent the emergence of vernacular because, simply, their emergence is part of divine practice, a deeply-rooted phenomenon in the human beings. Therefore, not all languages including Arabic were excluded from this divine tradition. Thus, the Arabic language was divided and it will continue to be divided into new dialects forever. Standard language remains immortal at the level of civilization for it the language of religion, science, literature, thought and the language of communication in society. All language, including Arabic, are subject to the change.

Strangely, there may be some who believe that some people spoke the standard language during the era of Murtada az-Zubaidi (passed away in 1205 A.H.). They are residents in a mountain called Ekada, near Zubaid in Yemen. Arabic language, as the case with other languages, must change. Those who do not believe in such a change do not believe in natural norms.

If it was not possible for the Arabs to continue using the language, which they mastered, given that they were the people of eloquence and rhetoric, how can a researcher bring them back to the standard language after all these years. If it was not possible to maintain the use of the standard language, it is impossible to bring the Arab societies back to the standard language. It is enough that specialists maintain and use the standard language in its platforms which include Arabic linguistics classes and Arabic grammar lectures taught in our schools and universities in which, unfortunately, a variety close to the vernacular is taught.

\section{Section Two: Link between Vernacular and Standard Language}

There is considerable variation in the speech of any one individual, but there are also definite bounds to that variation: no individual is free to do exactly what he or she pleases as far as language is concerned. Words cannot be pronounced the way the one please; to inflect or not inflect words such as nouns and verbs arbitrarily, or make drastic alterations in word order in sentences as the mood suits the speaker. The variation the speaker permitted has limits and these limits can be described with considerable accuracy. Individuals know the various limits (or norms), and that knowledge is both very precise and at the same time almost entirely unconscious (Wardhaugh, 2010).

Many researchers described the relationship between the standard language and the vernacular as rivalry and competitive relationship, rather than a relationship of integration and partnership. The vernacular does not prevent the standard variety of language from playing its role. Moreover, the duality of the standard language and the vernacular is not limited to the Arab community. The existence of two levels of language is an increasingly general phenomenon in every language. Indeed, the existence of dialects reflects vitality and regeneration. The Arabic dialects originated from the Standard Arabic in terms of their vocabulary, methods of derivation, structures, methods of expression and rhetoric. Vernacular dialects coexisted with the standard language to meet the daily needs of the people.

It is important to note that dialects were present in the public life of the Arabs during the formation of the common language, its growth and prosperity until the formation of its general framework. It shaped its independent entity, which we call today Standard Language. The Standard Language originated from the Arabic dialects. There is a special interactive relationship between the popular dialects and the common language of the same. An example of that is the notice of the researchers that the various Palestinian dialects are close in the language of the Palestinian Ataba, a kind of poetic folk art in Palestine. It shapes a common linguistic and artistic language among many dialects. (Note 3)

Vernacular remain a faithful guardian of the standard language. It is interesting to see the volume of the standard language use in dialects. Examples on that include:

1) Hushtu al-ibil " "حُشتُ الإبلَ": gathered the camels to make them drink water.

2) Al-khaysh "الخبش": clothes made from the poorest type of cotton.

3) Ar-Rash “"لرش": less rain.

4) As-Sa'ifah “ll':" silky sand.

5) Sibhah "سبحة": rosary.

6) Insataha "نسطح"':" laid down in his back. 
7)

8)

9)

10)

Safaqa al-bab “صفق الباب": closed it firmly.

Vernacular remains a faithful guardian for some ancient Arabic dialects like imbareh "مبارح/" (yesterday) which is still present in some Arabic dialects like the Palestinian dialect.

Therefore, it is important to monitor the relationship between the vernacular and the standard language and identify the role of each in the society. It is fair to borrow some words, phrases and structures from the standard variety to the vernacular to beautify it and to keep it close to the mother tongue. Thus, we protect the vernacular from the influence of foreign words which dominate it in the present. You can hardly find a sentence without a foreign word.

Perhaps, the phenomenon of necessitarianist vernacular is an indication of a miracle of Allah. How can the standard language remain vital and influential throughout these centuries? The Holy Quran presents evidence on this in chapter 15, verse 9 "We have, without doubt, sent down the Message; and We will assuredly guard it (from corruption). Thus the Quran is protected and that Quran cannot be protected without protecting the standard language. The verse indicates that Allah protects the standard language and made it immortal. Languages cannot maintain themselves for such a period. The necessitarianist vernacular are the best examples on that.

\section{Section three: status and importance of vernacular}

Linguistics in modern times aims to focus on the study of vernacular. It began in the West initially. Some researchers say that the first to study vernacular was Thomas Stephens. The study of vernacular is necessary and important for a number of reasons. For example, the historical study for any language requires studying its dialects. The standard language itself is a common language selected from ancient Arabic dialects. Some used the term allughah al-fuShah "اللغة الفصدى" (lit. standard language) to refer to this issue. Scholars selected the standard language from those dialects which had close relationship with the Quran and its recitations.

It is worth noting that a vernacular can guard the standard language in a better way than that which speakers of the standard language use to protect it. For example, the odd usage for (kah al-tashbeeh) $k$ " used for comparison has spread. Many people, for example, say: I am as a teacher, like my job; I, as a Muslim, refuse humiliation; we, as Arabs, honor the guest. This is an odd usage in Arabic.

The Arabic eloquent original style is not present. The correct way is to say, we the Arabs honor the guest. The vernacular here is consistent with the standard system and is not affected by the usages, which sound odd to the Arabic style. Speakers of vernacular still maintain the standard variety, with vernacular phrases as in: (we, oh the Muslims), (we, the Gazans love everyone), (We the Arabs do not accept humiliation) (Note 4) suggesting the usefulness of the study of the Arabic dialects. Such studies may contribute to the efforts of maintaining the standard language.

I would like to refer to what I call ilf lughawi "'لالف اللغوي" (linguistic familiarity) as humans tend to be close to what is familiar to them. Vernacular are familiar to humans. The flexibility of vernacular in not present in the standard language. Specialists cannot speak the standard language as flexible as they speak the vernacular. For many, vernacular is the mother tongue. Many people can only express themselves using the vernacular. Few can express their feeling using the standard language. Therefore, we find that poetry and beautiful arts are in vernacular.

The study of vernacular is of immense importance, especially the study of the Palestinian vernacular. It has a national value as part of the Palestinian entity. It shapes an important aspect in highlighting the Palestinian Arab identity in the light of the conflict on the land of Palestine.

\section{Scholars' Views on Vernacular}

Justin Barry denied the existence of vernacular and the real limits separating the speakers of one language in one country. He argues that language spreads throughout the country as a portrait with different colors mixing in a manner that does not allow seeing the gradual transition from one point to another. Johan Schmidt said that linguistic phenomena look like a wave after a wave and cannot have limits.

Miyeh opposed denying the dialects for their interference and lack of clear limits separating them. He argued that it is possible to distinguish dialects when identifying the features that appear in one place and are absent 
elsewhere. Thus we see the different opinions on the vernacular. The following three sections discuss the attitudes of scholars toward the vernacular.

\section{Section One: opponents of vernacular}

Vernacular resistance in the Arab community began long ago. Scholars made strenuous efforts to maintain the standard language by authoring books that dealt with the linguistic mistakes and warned against vernacular although they are tribal dialects. Scholars like az-Zamakhshari " الزمخشري began to challenge the Quranic readings which represent Arab dialects.

Ancient scholars described Arabic dialects as weak, ugly, bad, the language of abuse, evil, corrupt, and useless. Such dialects represented the Arabic vernacular long ago. The contemporary scholars described the contemporary vernacular as a complex linguistic problem, the problem of problems, a risk threatening us and our standard language, ailment, retrograde diseases, and decadent or corrupt.

A contemporary scholar says, "Vernacular is a disorder in the entity of the Arabic standard language and its history, became popular in the periods of weakness, ignorance and disintegration. The enemies of the nation saw a fruitful opportunity to achieve their objectives by maintaining and promoting vernacular." Some cite the Hadith of the Prophet "guide your brother, for he has been misguided" and state "This is how the companions knew the error in the language and considered it as a sin and mistake." This odd understanding creates confusion because the prophet meant the mistake not the sin and misguidance.

In the light of such concepts, the strange call for eradicating vernacular emerged. Supporting the standard language does not require fighting against vernacular given that vernacular never a threat to the standard language. (Note 5) It sounds paradoxical that those calling for the eradication of vernacular struggle to speak the standard language.

We do not serve the standard language, and do not respect vernacular. Weakness is the quality of the type of standard language used by our teachers, intellectuals and specialists. The westernization became the feature of vernacular due to the foreign words, which admire young generations.

There is a need to warn against the confusion between the fairness of resisting the replacement of vernacular by the standard language and the call to write in vernacular as well as the extreme views on both varieties, the standard and the vernacular, with special emphasis on the status of the standard language.

The opponents of the standard language use of dialects to abuse vernacular shall not drive us to dislike the vernacular. We are supposed to place each in its own field in an objective manner, which is consistent with the nature of language and society. Some researchers said that the use of vernacular dialects instead of standard language represents waging a war on the standard language. We started to notice the calls to resist such calls since Abdullah Nadeem in al-Ustaz “عبد اله نديم الاستاذ"Newspaper issued in 1892.

\section{Section two: Supporters of vernacular}

The confession of some grammarians regarding the errors in their speech is clear evidence of the influence of use. This can be attributed to the grammarians who grammars, imposing its dominance on the linguistic usage. The deviation of the linguistic norms is the key factor leading to the emergence of vernaculars. Some researchers blamed ancient scholars for failure to collect the ancient dialects, and their being contented with collecting only some of them.

The interest in discussing dialects is delayed in the present time. Studying dialects is the most up-to-date trend in linguistic research until it became an important field in the contemporary linguistic research. Special divisions were founded in some distinctive universities specializing in studying and analyzing the characteristics of such dialects. The first writing on Arabic dialects was a small paper entitled (Features of the Arabs Languages) by Hafni Nasif (Note 6), which he presented at a conference for orientalists in Vienna in 1304 A.H. He was a scholar who duly placed vernacular and standard language.

The Orientalists made great efforts to highlight the role of vernacular and its importance. Fletman, a German scholar, authored a book and entitled it The Arabic language of Damascus. Nellino, an Italian sscholar, authored a book and entitled it The Grammar and Vocabulary of the Egyptian Vernacular. Joe Wynot, an Italian scholar, authored a book and entitled it The Language of the Berbers. Father Vakarai, Italian, authored the Grammar of Spoken and Written Arabic in Tripoli; Panetta, Italian, wrote Spoken Arabic in Benghazi in two parts. In addition, Kantino, French, The Linguistic Geography of Vernacular in Algeria, and Nomads, Syrians, Lebanese and Palestinians; Woody Moreno, a Spanish, authored Moroccan Arabic Grammar; Charles Bella, Frenchman, wrote The Language of the Berbers, father Nakhlah Jesuit authored Grammar of the Lebanese-Syrian Vernacular; 
father Dalverni Jesuit wrote Introduction to the Lebanese Dialect in three volumes; Oandr and Edward Georgi, Americans, wrote The Arabic of Saudi Arabia; Makarios, American, authored a number of books including: The Elements of contemporary Arabic in five volumes; reprinted a number of times, Introduction to the Pronunciation and Writing of Contemporary Arabic in two volumes, and The Level of Contemporary Arabic in three parts.

Orientalists developed rules for vernacular, compiled dictionaries and incurred material costs in this regard aiming to protect the wealth of such vernacular. It is seldom to find an orientalist who does not add to his books a book on a vernacular of an Arab country, or a book on the grammar of that vernacular, or both. Some specialized in Arabic vernacular throughout their lives. (Note 7) However, their efforts were not limited to the scholarly theoretical study, and was rather a method to call for replacing the standard language.

Wilhelm Spita was a leading scholar calling for a shift toward the use of vernacular to replace the standard language. He was the first to write in the Egyptian colloquial Arabic. In addition, he authored a book and entitled it The Grammar of Colloquial Arabic in Egypt in 1880. This was followed by a call in the Egyptial Al-Moqtataf to write books in the vernacular. This was followed by Carl Flyers. The Britishers questioned the suitability of the Arabic language to the civilized life, and called for the use of the colloquial variety when teaching. Some of these include Moore, a judge in the Egyptian Court of Appeal, who authored a book and entitled it Cairo Language. In the book, he introduced grammar and suggested using Cairo dialect as a language in science and literature. He also proposed writing the same in Latin script. Sir William Wilcox, an irrigation engineer working in Egypt at the time, knew the issue again in 1926. He called the abandonment of the standard Arabic.

Some students of the orientalists glorified this call such as Ahmad Lutfi as-Sayyid " أحمد لطفي السيد", Slamah Musa

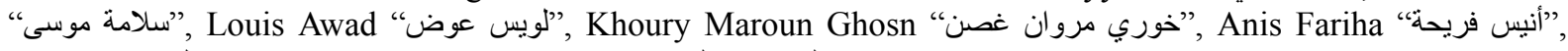
Saeed Aq1 “"سعيد عقل" "عيسى الكسندر معلوف", Issa Alexander Ma’louf "Such calls spread later.

The intolerance of some led them to disown the society of the standard language. They argue that the standard language was serving a community in which crimes were committed. In addition, they blamed Al-Aqqad for their love to the standard language, claiming that there is no need for the metaphors and similes, which characterize the Arabic language, calling for disregarding such metaphors. Furthermore, some scholars considering disregarding the standard language a mental and material relief. Surprisingly, some believed that the standard language deprived the Egyptians of the spirit of invention which can only be revived through the adopting the vernacular as the language of writing and authoring.

\section{Section Three: Moderates}

The reputation of the study of vernacular might have been affected by the fact that the first to undertake a study in the modern era was an orientalist in European universities in the nineteenth century, before they attracted the attention of Arab universities. However, ancient Arab scholars were interested in studying Arabic dialects. Abu Amr bin Ala says: "what reached you from what the Arabs said is little. Had it reached you in a sufficient manner, you would be enjoying abundance of science and poetry." Such benefits include proposing solutions to grammatical issues, according to some of the ancient Arabic dialects, regardless of the odd interpretations by some grammarians. Some argue that the inna "إنإن" in "Inna Hathan la Sahiran" "Indeed, these are two magicians" means yes. It was reported on authority on Ibn Azubayr that a man said to him: May God damn the camel which carried me to you. Ibn al-Zubayr replied: inna "ill" (yes) and its rider. Hathan is a nominal subject and Sahiran is a predicate. The sentence may be grammatically explained using the approach of Bilharith bin Ka'b, Khath'am, and Zabid, and others, who were committed to the alif (a) in the dual (al-Muthanna) in all the conditions, thus contradicting the views of most Arabs. ar-Razi considered this as the most convincing opinion of some Arabs.

The people of Kufa were more respecting to the Arab dialects. They were fully aware of the nature of language and understood it well. It is obvious that these dialects were a rich source to the standard language. Ibn Jinni integrated the study of dialects in his research work which he called "The Difference in Dialects and the Arguments thereto" (Note 8), which reflects a balanced view of the ancient writers on the vernacular.

Ibn Malik adopted the approach of the Kufi scholars and and elaborated on the Arab tribal dialects which were excluded by the scholars of Basra. He studies the Quranic readings, which represent Arabic dialects and believed that such dialects represent a fertile field of great importance. He documented some Arab dialects. The Andalusians were generally more moderate in their views on vernacular and did more studies on the same that scholars from the east.

The Language Complex in Cairo has highlighted the importance conducting a scholarly study on the modern 
Arabic dialects in Egypt and other Arab countries. The complex included a committee called (Dialects Committee), given the importance of studying the languages of the early Arabs and their dialects. Thus, it could be considered that maintaining the status of vernacular is a feature of the linguistic efforts in the modern era.

Some scholars called for promoting popular literature, studying the vernacular and did not underestimate the Quran, the language of the Quran or its value (Note 9). One of such scholar said, "The unreal fear on the standard language, and thus on the Quran, is no longer existing. This is because the Quran and the language of the Quran are stronger and firmer than being affected by promoting any interest in vernacular. Quran and the language of the Quran are the source of life for such vernacular" (Note 10).

Thus, vernacular are not an enemy that we should resist. It is better that we feel pride in speaking our vernacular, feel being affiliated to it as it is an integral part of our heritage. It is thus more important than the traditional dress, which is a source of pride to us. If it is allowed for us to feel pride in having our traditional dresses and tools, we should feel more proud to speak our vernacular. Vernacular language closer to us than our dresses and tools.

Among the Muslim nations, only the Arabs called for abandoning their vernacular. The Turks maintained their languages; the Afghans, Indians, and others. Vernacular are closer to the standard language than such languages which is a truism of the human life.

The call for unifying the entire Arabs vernacular in one dialect, as one scholar said, is impossible. It indicates unfamiliarity with the nature of the human language. Antoine Meyer says: it is evident that dialects are not united.

The vernacular is part of the standard language and must therefore remain so as long as the standard language is surviving. This means that the Arabic vernacular shall remain close to the standard language. Scholars of the vernacular shall seek to strengthen the connection between the two and try to add some standard language terms to the vernacular. They shall also seek to prevent such vernacular from being affected by other languages.

It is possible to find some vernacular words more accurate than the words used by the people of eloquence nowadays. An example of that is the word urus as compared to urs used by many of the people of eloquence. Therefore, some researchers to a middle stand in their views on the vernacular and refrained from taking extreme views on the same.

\section{Vernacular: Inevitable Reality}

Language researchers need to have a tolerant view on language. This tolerance is governed by the balanced perception of the subject of languages. We shall see in the following three sections how we shall have a balanced view on the vernacular.

\section{Section One: Fields of Vernacular}

A historical fact worth mentioning here is that the different Arabic languages which ancient scholars' studies were only vernacular, as per the meaning of vernacular nowadays. This means that such vernacular were the language of daily communication between the members of the community. The standard language aimed to fulfill a noble message; it is the language of the Islamic sharia, promotes the status of humans, protect the identity of the nation, guard the heritage, ensure a future development; benefiting from its wealth of knowledge and science. The standard language never aimed to replace the vernacular.

To every context a saying. Thus, vernacular suit their context; the standard suits its platforms. The vernacular main field of use is the affairs of everyday life at home, in the market and workplace. Vernacular is characterized by diversity; its linguistic lexicon is limited in its words count; the methods of expression are not abundant. It aims to meet the needs of its speakers. The standard language is the language of science, literature, thought, civilization, imagination and creativity, since the Quran was revealed in it and when it became the language of religion. It used to coexist with vernacular, each fulfilling its role in its field, in a complementary linguistic activity of the society (Note 11).

There is a real need to achieve balance between the standard language and vernacular. This shall not be interpreted as giving preference to the vernacular. We shall use the standard language in its fields.

The vernacular reflects its own importance and necessity while the standard language reflects has its own mission and status. The standard is used in mosques, study sessions in mosques, classrooms in universities, schools, cultural centers, newspapers, magazines and publications, radio stations, satellite channels, media, articles and high literature.

The vernacular is used in our homes, events and social gatherings, picnics, with friends, relatives, neighbors, in 
the streets and markets.

The role of any of the two languages varieties is important and thus cannot be denied. The standard cannot replace the vernacular simply because we cannot teach all people to master the standard variety. This was not even feasible for the greatest grammarians during the era of the Islamic caliphate. Such linguists were not able to properly maintain the standard language despite the fact that they were the most eloquent people. Since it was not possible to protect the standard and prevent people from using vernacular, it is impossible to get people back to use only the standard.

Furthermore, we are proud of the traditional dress, which grandmothers wore, although they are not used. We feel pride in having our traditional mills despite discontinuing their use due to the technical progress. This applies to other traditional items, which our people used before the migration of our country, Palestine. We do not deny our people's right to feel pride in having traditional items. However, it is more important to pay attention to the vernacular that cannot be ignored. Therefore, care should be directed towards the vernacular, as it is the language used by our fathers and grandfathers. Our language is more precious than out clothes.

\section{Section two: Vernacular social mission}

"Al-Farra' entered the place of ak-Rashid one day and spoke in vernacular. Jafar bin Yahya said: O the Emir of believers, "he deviated from the standard norm." ar-Rashid told al-Farra, "do you deviate from the standard norm, O Yahya?" He said, "O, Emir of the believers, the Bedouin are used to grammatical expressions of language, and the people in urban areas deviate from the standard linguistic norms. I do not deviate from the norms when I write or memorize, but I do so when I get back." Ar-Rashid liked his reply."

Al-Asfahani reported that Marwan ibn Abi Hafsah confronted Hammad al-Rawiya in front of al-Walid ibn Yazid and said, "How can you not abide by the language norms in this council," The sheikh came and said: O! My nephew, I speak to the common people and use their language. Ahmad Shawqi who is the prince of eloquence and literature organizes Mawawil in the Egyptian colloquial Arabic.

This clearly indicates the extent of the impact of the environment and society on the human language even if the speaker was at the same level as al-Faraa, Hamad or Shawqi in the modern era. Human beings cannot be isolated from their surroundings and environments. Vernacular is strongly linked to the society because it is the language that they talk. Therefore, there was no surprise that some researchers said that the early grammarians ignored the social reality of language when they looked into Arabic as standard language only. Thus, we must study the vernacular to understand the nature and culture of the society.

Language is a social phenomenon and is affected by the society to meet its needs and accommodate the different aspects of life. As long as the society is in continuing movement and permanent change; language must follow the same track. A key feature of language lies in its being a social phenomenon. It is a natural human phenomenon that cannot be ignored. Standard language is only the common language of Muslims just as each nation with a civilization seeks to connect all of its citizens through one language. in Ancient times, Arabs spoke in various dialects from which scholars tried to introduce what was called then Standard language. Therefore, we still hear in the Standard language about the language of Quraysh, Tamim, Qays, Tiey, Hadhil, and other languages of the Arabs. Scholars selected some of those languages and ignored others. This indicates the natural difference among the languages people speak. Grammar books cited poetic examples which do not necessarily reflect the Standard.

We knew that Holy Quran included examples of Arab dialects and the Standard language. The Prophet sometimes talked in varieties, i.e. vernaculars, other than the standard for social reasons. We saw that the Prophet was appeasing an Arab tribe according to its dialect when pronouncing the hadith, "It is not righteousness to fast when traveling." Although the Prophet was the master of eloquence, he obviously preferred the vernacular to strength the relationship with the targeted tribe. If the Standard variety achieved was sufficient to achieve his goal, the Prophet would not use the vernacular of that tribe. It was narrated about 'Aisha, may Allah be pleased her, that she asked permission from the Prophet to meet Abi al-qa'ays, he said: you asked for a permission of me while he was your uncle by breastfeeding. The Prophet thus replaced the $k$ sound in ammuk "ع "عour uncle) by $j$, according to the dialect spoken in Yemen. It was claimed that he Prophet talked only Standard language; Ibn al-Athir replied: He was talking many Arabs languages.

Dialect originally means strong attachment for something. (Note 12) Dialect includes the meaning of being attached to its use and have a sense of belonging to it. People like what belongs to them. One of the key properties of man is the dialect, which belongs to him and his society. Therefore, the presence of dialect should promote loyalty to the standard, and the presence of vernacular to the common language, which the Arabs define 
as language. This results in linguistic familiarity that is considered as one of the most important pillars of cohesion and coherence of the community. People love their language and feel proud speaking it. Their loyalty is strengthened when they see the common language containing words and phrases from the language that belongs to them. It is no surprise that some researchers interpret the revelation of the Holy Quran in seven dialects which allowed the Arabs to read the Quran in some dialects to facilitate understanding it. (Note 13)

Unfortunately, some researchers claim that the vernacular threatens the Arab unity and that compulsive linguistic mixing cracks social unity. The labeling of this mixing as compulsive is confusing. It is a normal process that is not limited to a nation. Abdullah an-Nadeem depends on the vernacular in his political essays in Egypt after he paying attention to the role of vernacular in awakening public awareness. He issued his journals Abu Nazara, at-Tankit and at-Tabkit and struggled against those who distort the reputation of the vernacular and entered into conspiracies against it.

Therefore, a vernacular plays a very important role represented in its social mission. Therefore, we must pay attention to it and attempt to promote its status. Al Jahith said, "If you hear about anecdote of the common people or a droll story of a villain (Note 14), do not apply grammar to it to try to find a suitable utterance to it because you would be distorting its connotations." (Note 15)

\section{Section three: Vernacular: rights and duties.}

There are rights due on us towards the vernacular given its importance and its necessity and mission as explained in this paper. We should also maintain the standard language and be flexible in dealing with the movement of the tongue.

If we feel pride in having our potteries, embroidered clothes and mill of our ancestors, it is more honoring to feel pride in relation to the language of our ancestors. The researchers who claim that the vernacular is a danger which threatens our standard language should be aware of the dangers which threaten the standard and the vernacular together. Vernaculars were never a threat against the standard language.

It is utterly disappointing to see that the teacher of grammar who speaks in the vernacular in the classroom is a real danger to the standard language. Such teacher reflects a distorted image of the wonderful standard language. When using the vernacular to teach the standard, he reflects a distorted image of the standard. The worst of those images is that students may understand that the standard is not practical and realistic because if it was so, the teacher would use it.

It is essential to safeguard the vernacular against the dominance of non-Arabic words which make people think of them as the most beautiful. This influences our spirituality the same was it influences our poor linguistic inferiority. It is better to use a solely Arabic vernacular than to use a vernacular which contains foreign words. Some of the writers call for using foreign words in our language as al-Atumbil instead of the car.

We should also try to strengthen the relation between the vernacular and the standard language. In addition, we must fill the gap between the vernacular and the standard language forever. This mission can be accomplished through various means mentioned by some researchers. However, we should be aware that permanently filling the gap is impossible. Some researchers paid attention to this point and said, "It seems that filling that gap permanently is impossible." We agree with him after deleting the word (it seems) because the issue is impossible.

It is very rewarding to seek to spread the standard words in our vernacular through serious programs planned well in our schools, audio-visual media and other means. I can suggest an example in this section about using missing authentic Arabic words for things, which are still in use in our daily lives. Those words are enormous and people may seize the opportunity to use them if we have a good publicity. The examples of this proposal include but not limited to:

Words about food for use at home or in luxurious restaurants:

- Sulfa "سلفة" (Starters): the food that is eaten before lunch as a starter.

- Khubz malhuj “" "نبز ملحوق" Urgent bread.

- al-Qarqur "القرقور": the thing that is put in the bottom of the pot.

- al-Mihdi "الدهtي": A dish that contains a food as a gift.

Words suggested for the builders:

- alkablu "الكابل": two or more wires running side by side twisted or braided together.

- al-Misaja "لكساجة"': piece of wood used to put mud on the wall, it means: paint the wall with mud. 
- al-Mislafa "لألسلافة"): an implement consisting of a heavy frame set with teeth or tines that is dragged over plowed land to break up clods and remove weeds.

Words suggested for clothes:

- al-Baqira or al-Khay'al: shirt that has no sleeves.

- al-Makhnaq: Rag is put in the neck of the boy to protect his clothes from saliva.

- al-Ghifara, al-Waqaya, al-Waqiya, ash-Shantaqa: a square of clothes worn as a covering for the head.

- al-Maghlafa: al-'Infaqa, a small patch of facial hair just below the lower lip and above the chin.

- al-Idmama (Package) of books: al-Idbara, its plural is al-Adamim (groups).

- Al-Hirshifa a piece of cloth used for drying oneself or wiping things dry, some called it as Jafafa (towel).

\section{Conclusion}

It is necessary that we promote the usage of Standard Arabic through speaking, listening, holding conferences, seminars, contests, festivals in this regard. We should also promote the interaction with the standard language since childhood by focusing on the interest of children towards. Successful cartoon films can greatly contribute to spreading the use of Standard Arabic.

We cannot eliminate the role of the vernacular. In this research, I confirmed that the vernacular is a divinely sanctioned practice and therefore cannot be eliminated. However, it is necessary to use the vernacular alongside with a standard language. In addition, it is necessary for the standard language to remain the language of teachers during the lessons in our schools, universities and the competent language centers. It shall also remain the language of the visual, written and audio media such as satellite channels, radio stations, newspapers and magazines. We shall also use it in general lessons, our speeches, and lectures in various fields including mosques, conferences, festivals, seminars and other places.

The awareness of the role of the standard language and its importance in our life helps us preserve the authenticity of the standard language as an integral part of our civilization. Through our care, interest and attention towards the vernacular, we will maintain human language given that people cannot live without things they love and given that the vernacular is desirable for humans. Therefore, there should be balance between the two varieties. Thus the standard language takes the lead of time and place. We shall seek to avoid extreme views with regard to our view on the standard language. ht. We are proud of the standard language and we consider it as the truth in our daily lives so we must avoid radicalism and fanaticism in its love to preserve it and maintain it from harm and abuse. It shall suffice us in this context to mention that Prophet refused the extreme acts of worship. One of his companions One of them said: "As for me, I shall offer Salat all night long." Another said: "I shall observe Saum (fasting) continuously and shall not break it". Another said: "I shall abstain from women and shall never marry". The Prophet came to them and said, "Are you the people who said such and such things? By Allah, I fear Allah more than you do, and I am most obedient and dutiful among you to Him, but still I observe fast and break it; perform Salat and sleep at night and take wives. So whoever turns away from my Sunnah does not belong to me". (Note 16)

Balance is required in everything and exaggeration shall be avoided. Preserving the status of the standard language does not mean contradicting a divinely sanctioned practice. It is Allah decree that people differ with regard to the use of their languages. Arabic is no exception. The only exception in this regard is that Allah informed us that $\mathrm{He}$ will protect it. This is limited to the fields of the standard language.

The importance of examining the vernacular lies in:

- Highlighting the researches targeting the old Arabic dialects, the modern Arabic dialects kept some qualities related to the ancient Arab dialects. (Note 17)

- Bridging the gap between the contemporary Arabic dialects and the standard Arabic language.

- Linking the linguistic phenomena in the modern dialects with their origin in the ancient Arabic dialects.

- Studying the movement of migrations of the Arab tribes after Islam through the dialects of those tribes in the places to which they moved.

- Helping the linguistic researcher to know and understand the linguistic development for the Arabic language and to strengthen the language lesson. (Note 18)

- Modern Arabic dialects is an authentic source of knowledge on the ancient Arabic dialects. 


\section{References}

Al-Barghouthi, A. L. (1986). Palestinian Ataba Diwan. Jerusalem, Palestine: Al-Bayader Press Foundation.

Al-Bukhari, A. A. M. I. (1987). Sahih al-Bukhari (part 6), edit: Mustafa Deeb al-Bagha. 3rd edition. Beirut, Lebanon: Dar Ibn Kathir wa al-Yamamah.

Al-Hamad, G. Q. (2005). Researches in Standard Arabic (1st ed.). Amman, Jordan: Dar Ammar.

Al-Hamidi, M. F. (2002). Al-Jam'e bayn as-Sahihyn al-Bukhari wa Muslim (part 4). Edit: Ali Hussein al-Bawab. 2nd edition. Beirut, Lebanon: Dar Ibn Hazm.

Al-Jahiz, A. O. A. B. B. (1998). Al-Bayan wa at-Tabyein (part 4). Edit: Abdul Salam Haroun. 7th edition. Cairo, Egypt: al-Khanji Library.

Al-Zubaidi, A. F. M. M. (n. d.). Taj al-Arous min Jawahir al-Qamous (part 40). Edit: a group of editors: Dar al-Hedaya.

Arabic. (n. d.). Online Etymology Dictionary. Retrieved from http://www.dictionary.com/browse/arabic

Az-Zamakhshari, M. J. A. O. (1998). Basis of Rhetoric (part 2). Edit: Muhammad Bassil Eyoun as-Soud. 1st edition. Beirut, Lebanon: Scientific Books Library.

Az-Zamakhshari, M. O. (n. d.). Al-Faeq fi Gharib al-Hadith (part 4). Edit: Ali Muhammad al-Bijawi and Muhammad abu al-Fadil Ibrahim. 2nd edition. Beirut, Lebanon: Dar al-Ma'arifa.

Ibn Manzour, A. F. M. M. (1882). Lisan al-Arab (part 15). Beirut, Lebanon: Dar al-Fikr and Dar Sader.

Ibn, J., \& Abul Fateh, O. (n. d.). Al-Kh̆așāìș (part 3). Edit: Abdul Hakim bin Muhammad. Cairo, Egypt: At-Tawfiqiyah Library.

Kareem, M. (1986). Brief in the Arab Dialects. Tanta, Egypt: At-Turki for Computer and print al-Ofist.

Shafi'e ad-Din, M. (2007). Arabic dialects and their relationship in Standard Arabic. International Islamic University Chittagong Studies, Volume IV, December.

Sultani, M. A. (2001). Researches in the Language (1st ed.). Damascus, Syria: Dar al-Asmaa.

\section{Notes}

Note 1. Arabic. (n. d.). Online Etymology Dictionary. Retrieved from Dictionary.com website http://www.dictionary.com/browse/arabic

Note 2. Ibn Jinni, al-Kḩașâ̄ iṣ 1/44.

Note 3. Al-Barghouthi, Palestinian ataba Diwan 6.

Note 4. Dialect here is dialect of Gazans in Palestine and it look like the dialect of the Levant.

Note 5. Al-Barghouthi, Palestinian ataba Diwan 41.

Note 6. Was born in Egypt and received his education in Al-Azhar. He worked in education and judiciary and joined the Urabi Revolt as a preacher. He traveled a lot and chaired Al-Ahleyah University when it was established in 1908. In addition, he contributed to the establishment of the First Linguistic Association. He composed poem. He passed away in Cairo in 1919. See az-Zarkali, Al-A'lam 2/265.

Note 7. Sultani, Language Research 74.

Note 8 . Ibn Jinni, Al-Khasa' is 2/7.

Note 9. He criticized the standard Arabic and said that it was poor. See: al-Barghouthi, Palestinian ataba Diwan 10.

Note 10. Al-Barghouthi, Palestinian ataba Diwan 9.

Note 11. Al-Hamad, Research Papers on the Standard Arabic pp. 186-187.

Note 12. Az- Zamakhshari, the basis of rhetoric 2/186. Ibn Manzour, Lesan al-Arab 2/359.

Note 13. Kareem, brief in the Arab dialects 105.

Note 14. Al-Jawhari, Al-Sihah, 2/1458, Lisan aArab 12/368, Zubaidi, Taj al-Arous 28/486, 33/22.

Note 15. Al-Jahith, al-Bayan wa al-Tabyeen 1/146.

Note 16. Al-Bukhari, in his Sahih [No. 4776] 5/1949. Ibn Jaban, in his Sahih [317] 2/20. al-Bayhaqi, in his Great 
Sunan [No. 13226] 7/77. al-Hamidi, aj-Jam'e bayn as-Sahihyn [No. 1998] 2/456

Note 17. Shafi'e ad-Din, Arabic dialects and their relationship in Standard Arabic 77.

Note 18. Kareem, brief in the Arab dialects 43.

\section{Copyrights}

Copyright for this article is retained by the author(s), with first publication rights granted to the journal.

This is an open-access article distributed under the terms and conditions of the Creative Commons Attribution license (http://creativecommons.org/licenses/by/4.0/). 